\title{
Optimization of the process parameters in rice mill using Response surface methodology (RSM)
}

\author{
Kumkum Pandey* and Deepa Vinay \\ Technology, Pantnagar-263145, (Uttarakhand), INDIA \\ Corresponding author. E-mail: Kumkum.pandey.unique@gmail.com \\ Received: October 20, 2015 Revised received: April 27, 2016; Accepted: July 18, 2016
}

Department of Family Resource Management, College of Home Science, G. B. Pant University Of Agriculture \&

\begin{abstract}
Objective of the current study was to analyze a wooden plank used as a loading ramp to perform manual handling task with a view to redesign and develop the new one for agriculture. Developed ramp was more wide, static and non slippery than the wooden plank. For this purpose experiments were conducted on a group of 10 experienced manual handlers in the KLA rice mill of Rudrapur Block, district Udhamsingh Nagar, Uttarakhand, India. The reliability and validity of the developed, modern loading ramp was assessed by using response surface methodology in terms of change in MSD, heart rate and VO2 max. Therefore RSM was applied to optimize the operating parameters of ramp such as load weight, height of ramp and time. As per Box Behenken design total 17 experiments were carried out. Each parameter was varied over three levels as load weight of 40,50 and $60 \mathrm{~kg}$., height of ramp 3, 4 and 5 feet, and the time viz. 3, 4 and $5 \mathrm{~min}$. ANOVA test and coefficient of determination $\left(R^{2}\right)$ were applied. In result it was observed that use of developed pant loading ramp was able to reduce heart rate of selected respondent's from 135.4 beats/min. to 126.76 beats/min., MSD from 85.45 to $22.80 \%$ and VO2 max from 39.45 to $34 \mathrm{~L} / \mathrm{min}$.
\end{abstract}

Keywords: Ergonomics, Musculoskeletal disorders, Volume of oxygen uptake

\section{INTRODUCTION}

According to Genaidy et al. (2003) operations related to manual handling include the acts of lifting, lowering, carrying, pushing, pulling, and holding items. National Institute for Occupational Safety and Health, 1997 reported that when handling and lifting items manually, there is always potential for injuries such as strains, sprains, fractures, cuts, lower back pain due to awkward postures, muscle fatigue and MSD problems. Among the injuries reported in industry, MSD have been recognized as one of the leading problem. Besides these researches also shows a significant linkage between musculoskeletal injuries and manual handling (Edlich et al., 2005; Hoozemans et al., 1998). It is found that manual handling injuries are a major burden to society, organizations and the sufferers themselves and the financial costs are estimated to be rising continuously.

Recent statistics from the Health and Safety Authority (2007) indicate that, approximately one third of all reported work-related incidents are triggered by manual handling. The proportion of incidents associated with manual handling is particularly high in the wholesale and retail trade $(47 \%)$, manufacturing (40\%) and health and social care $(38 \%)$. The most common type of injury in 2006 was 'physical stress or strain to the body' $(41 \%)$ and the most frequently injured body part was the back $(24 \%)$. Health and related occupa- tions are ranked sixth in the 'top 10 occupations of workers injured' (Health and Safety Review, 2007).

However workers in the rice mill industry have a high risk of musculoskeletal disorders because they are principally involved in MMH task. Although today the tasks or processes are being mechanized even then, many tasks are still performed manually in the rice mills and the worker were sufferings from hazards like, force, awkward postures, and repetitive motions that can lead to injuries, energy and time waste. Furthermore it was noted that rice mill workers were using the wooden plank for loading and unloading task which was narrow, short, non static and slippery. It was adjusted on different loading vehicle by using a drum which takes approx $45 \mathrm{~min}$ of time period. To avoid these problems, need was felt to redesign and develop loading ramp ergonomically and to test its validity and reliability by using the response surface methodology. Thus the objectives of the present study were to verify the newly developed pant loading ramp by using the RSM statistical technique and to evaluate the relative advantages and users acceptability.

\section{MATERIALS AND METHODS}

This study researcher observed the prevailing working environment and tool (wooden plank) for a period of 1 year that is used by the workers. Thereafter a need and scope was assessed for redesign and development of 
loading ramp and a new aluminium pant loading ramp was developed.

Thus newly developed pant loading ramp (length of 19 feet, width of 2 feet and adjustable between 2.5-5 feet) was statistically tested by conducting the experiments of RSM technique and thereafter its acceptability and relative advantages were rated by taking the responses of workers. To fulfil this objective subjects were familiarized with the experimental procedure and some personal and physiological variables of the workers were also taken.

Subjects: A group of 10 male subjects were recruited. These workers met the following criteria a minimum of 5 year experience, age between 20-30 years, a low lifetime incidents of injuries, involve in loading and unloading of rice sack and had a good physical fitness. All subjects were belonging to the very low socio-economic status and never received any ergonomic training and each subject perform three trials for each experiment.

Locale: Study was done in the KLA rice mill plant of Rudrapur block, district Udhamsinghnagar, Uttarakhand, India.

Response surface methodology (RSM) analysis through box behenkan experiment design: RSM is a collection of mathematical and statistical techniques that are useful for the modelling and analysis of problems in which a response of interest is influenced by several variables and the objective is to optimize this response (Natarajan et al., 2011). Hence, RSM technique was applied to test the efficacy of developed pant loading ramp in terms of heart rate, MSD and VO2 max. Thus to conducting RSM analysis of the loading ramp, the selected process variables (load weight, height of ramp and time) were varied up to three levels. Load weight varied as 40,50 and $60 \mathrm{~kg}$., height of the ramp as 3, 4 and 5 feet and time was also varied as 3, 4, and 5 min. (table 2). The Box Behenken design was used for modelling of experiments. Where total number of experiments based on RSM was observed to be 17 as depicted in table 5 .

The selected responses were musculoskeletal discomfort (MSD), heart rate (HR) and maximum volume of oxygen uptake (VO2 max) (Table. 3). Optimization experiments were designed with the help of design expert 8.06 software. Besides this surfur software 9.0 was also employed for the graphical optimization of the multiple responses. The table, 1, 2, 3 and 4 showed the selected parameters of the study as constant, independent, dependent and process variables with their levels.

Design of experiment: Design of experiment is required if we wish to extract meaningful conclusions from the measured responses. Adequate experimental design requires competent process knowledge for selection of the factors and their levels that could possibly significantly influence the response. Therefore, the experimental design were performed with the help of design expert 8.06 software and brainstorming ap- proach as shown in table 4 and 5.

Eqn. 1 shows about the method of calculating coded value: Besides response surface methodology, user acceptability of pant loading ramp was also assessed by using a developed interview schedule.

Coded value (CV): $\quad x$-mid value (centre point Differenceintmalgap) Eqn. 1

\section{RESULTS AND DISCUSSION}

General characteristics of selected mill workers: The general characteristics of selected workers for the ergonomic experiments to carry out the identified maximum drudgery prone activities of $\mathrm{MMH}$ task revealed that the mean and SD of age and height of the workers was calculated as $29.03 \pm 4.23$ years and $162 \pm 12.67 \mathrm{~cm}$. Whereas the computation of mean and SD values of body weight, BMI (body mass index), lean body weight and ideal body weights was $53.65 \pm 9.28 \mathrm{~kg}, 20.84 \pm 3.41 \%, 44.4 \pm 5.57(\mathrm{~kg})$ and $53.6 \pm 8.67 \mathrm{~kg}$. The mean of aerobic capacity estimated based on heart rate was $39.45 \mathrm{l} / \mathrm{min}$ with $\mathrm{SD}$ of \pm 5.67 . The mean and SD of blood pressure and pulse rate was $117.53 / 72.15 \pm 12 / 8.4 \quad$ (systolic/diastolic) and $76.54 \pm 7.56$ beats/min. While the mean body temperature was $96.50{ }^{\circ} \mathrm{F}$ with SD value of \pm 2.6 , which was in the normal range. Calculated MSD rate was $85.45 \%$

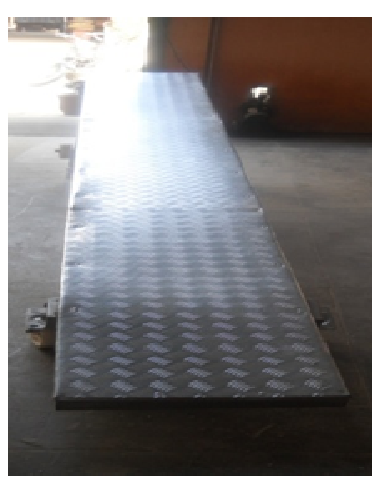

Front View

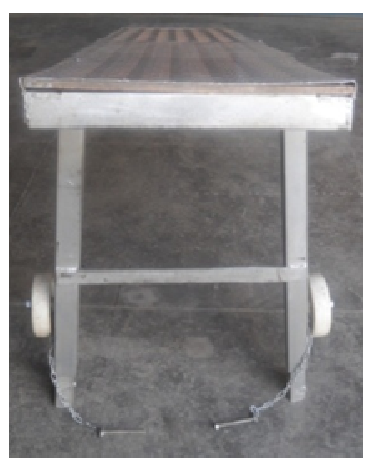

Top view

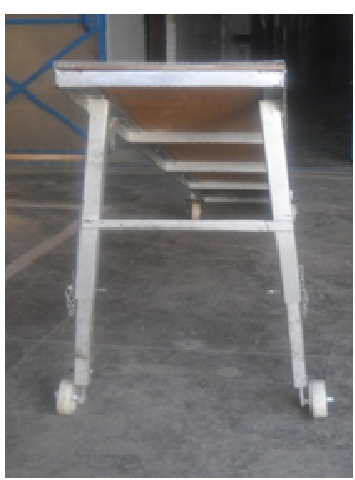

Internal view

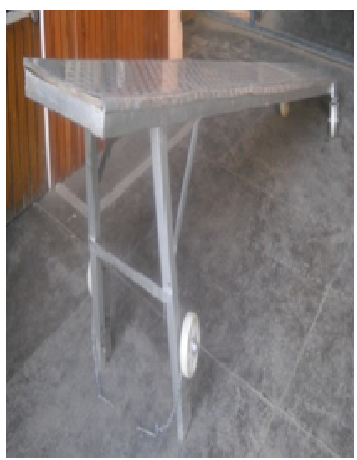

Side view
Plate 1. Different views of improved loading ramp. 
Table 1. Constant parameters for optimization.

\begin{tabular}{lll}
\hline SI. no. & Parameters & Value/name \\
\hline 1 & Back loading & - \\
2 & Ramp length (16) & Feet \\
\hline
\end{tabular}

Table 2. Independent variables for optimization.

\begin{tabular}{|c|c|c|c|c|}
\hline $\begin{array}{l}\text { SI. } \\
\text { No. }\end{array}$ & Parameter & & $\begin{array}{c}\text { Leve } \\
1\end{array}$ & Range \\
\hline 1 & $\begin{array}{l}\text { Load } \\
\text { (kilogram) }\end{array}$ & weight & 3 & $40,50,60$ \\
\hline 2 & Height (feet) & & 3 & $3,4,5$ \\
\hline 3 & Time (minute) & & 3 & $3,4,5$ \\
\hline
\end{tabular}

Table 3. Dependent variables for optimization.

\begin{tabular}{cll}
\hline $\begin{array}{c}\text { SI. } \\
\text { No. }\end{array}$ & Parameter & $\begin{array}{l}\text { Value/ } \\
\text { name }\end{array}$ \\
\hline 1 & MSD (Musculoskeletal discomfort) & \%age \\
2 & $\mathrm{HR}$ (Heart rate) & Beats/min. \\
6 & $\begin{array}{l}\mathrm{VO}_{2} \max \text { (Volume of maximum } \\
\text { oxygen uptake) }\end{array}$ & $\begin{array}{l}\mathrm{L} / \mathrm{min} \text { (litre/ } \\
\mathrm{min})\end{array}$ \\
\hline
\end{tabular}

Table 4. Process variable and their levels.

\begin{tabular}{llccc}
\hline \multicolumn{1}{c}{$\begin{array}{c}\text { Independent } \\
\text { variable }\end{array}$} & \multicolumn{3}{c}{ Codes level } \\
\hline Name & $\begin{array}{l}\text { Co } \\
\text { de }\end{array}$ & -1 & 0 & 1 \\
\cline { 3 - 5 } $\begin{array}{l}\text { Load weight } \\
\text { (kilogram) }\end{array}$ & $\mathrm{X}_{1}$ & 40 & 50 & 60 \\
$\begin{array}{l}\text { Height of ramp } \\
\text { (feet) }\end{array}$ & $\mathrm{X}_{2}$ & 3 & 4 & 5 \\
Time (minute) & $\mathrm{X}_{3}$ & 3 & 4 & 5 \\
\hline
\end{tabular}

by using Nordic questionnaire (Kuorinka et al.,1987).

Need assessment for technology development : The MMH work had the highest rate of job related illness and injury. The statistics shows that a great number of accident occurred in $\mathrm{MMH}$ tasks compared to other tasks. Seeing this as a huge problem and the needs of a

Table 5. Experimental designs. quick solution onto it, it was decided to work on problem that focuses on the analyzing several activities in manual loading including the causes and the consequences. In order of becoming a developed country, the researcher sees the importance of overcoming the tangible mislead of manual handling in the nation by improved designing of conventional existing which were cost effective and based on the ergonomic principles. Keeping the above facts in mind the need assessment was done to identify issues and problems associated with $\mathrm{MMH}$ activities and possible solutions at a KLA rice mill.

From this perspective a participatory workshop was arranged for need analysis. The theme "Problems while Mill Activities" of participatory workshop (PW) was defined by active discussion of the entire worker. The environmental condition was flexible and informal with access to refreshment and materials for visualizing the output of the PW. The head of the workers were also participated as a neutral person to guide the PW. Workers were seated after lunch in afternoon in a "U" shaped informal arrangement. The workers were asked to freely highlight all the problems related to their present work situation or conditions, with reference to the PW theme. The workers were tried to focus only on the negative aspects of the PW theme, and possible encumbrances that the workers wanted to change. Each worker described in short, a concrete problem (risk factors identified) that he had experienced. The process continued until workers could not come up with any new problem. Each of the problems mentioned were taken one by one by the group to develop possible solution. In result it was found that all the selected subjects were agreed that there is a need to change the economic, technical, organizational and other factors of KLA, rice mill industry.

Design approach for redesigning of conventional wooden plank : The design of any tool/equipment or

\begin{tabular}{ccccc}
\hline Std & Run & $\begin{array}{c}\text { Factor } \mathbf{X}_{\mathbf{1}} \\
\text { Load weight }(\mathbf{k g} .)\end{array}$ & $\begin{array}{c}\text { Factor } \mathbf{X}_{\mathbf{2}} \\
\text { Height of ramp (feet) }\end{array}$ & $\begin{array}{c}\text { Factor } \mathbf{X}_{\mathbf{3}} \\
\text { Time (minute) }\end{array}$ \\
\hline 1 & 17 & -1.00 & -1.00 & 0.00 \\
2 & 14 & 1.00 & -1.00 & 0.00 \\
3 & 6 & -1.00 & 1.00 & 0.00 \\
4 & 13 & 1.00 & 1.00 & 0.00 \\
5 & 15 & -1.00 & 0.00 & -1.00 \\
6 & 16 & 1.00 & 0.00 & -1.00 \\
7 & 2 & -1.00 & 0.00 & 1.00 \\
8 & 7 & 1.00 & 0.00 & -1.00 \\
9 & 1 & 0.00 & -1.00 & -1.00 \\
10 & 3 & 0.00 & 1.00 & 1.00 \\
11 & 10 & 0.00 & -1.00 & 1.00 \\
12 & 8 & 0.00 & 1.00 & 0.00 \\
13 & 9 & 0.00 & 0.00 & 0.00 \\
14 & 5 & 0.00 & 0.00 & 0.00 \\
15 & 11 & 0.00 & 0.00 & 0.00 \\
16 & 12 & 0.00 & 0.00 & 0.00 \\
17 & 4 & 0.00 & 0.00 & \\
\hline
\end{tabular}


Kumkum Pandey and Deepa Vinay / J. Appl. \& Nat. Sci. 8 (3): 1267 - 1277 (2016)

Table 6. Experiment data for various responses from RSM technique.

\begin{tabular}{|c|c|c|c|c|c|c|c|}
\hline & & Factor $\mathrm{X}_{1}$ & Factor $X_{2}$ & Factor $X_{3}$ & Response 1 & Response 2 & Response 3 \\
\hline Std & Run & $\begin{array}{c}\text { Load weight } \\
\text { (kilogram) }\end{array}$ & $\begin{array}{c}\text { Height } \\
\text { (feet) }\end{array}$ & $\begin{array}{c}\text { Time } \\
\text { (minute) }\end{array}$ & $\begin{array}{c}\text { MSD } \\
(\%)\end{array}$ & $\begin{array}{c}\text { HR } \\
\text { (beats/min.) }\end{array}$ & $\begin{array}{l}\text { VO2 max } \\
\text { (l/minute) }\end{array}$ \\
\hline 1 & 17 & -1 & -1 & 0 & 30 & 123.1 & 35.3 \\
\hline 2 & 14 & 1 & -1 & 0 & 50 & 126.25 & 41.09 \\
\hline 3 & 6 & -1 & 1 & 0 & 35 & 124 & 27.84 \\
\hline 4 & 13 & 1 & 1 & 0 & 55 & 128.12 & 50.28 \\
\hline 5 & 15 & -1 & 0 & -1 & 20 & 128 & 36.31 \\
\hline 6 & 16 & 1 & 0 & -1 & 55 & 130.33 & 36.12 \\
\hline 7 & 2 & -1 & 0 & 1 & 35 & 127 & 41.27 \\
\hline 8 & 7 & 1 & 0 & 1 & 60 & 131.6 & 23.72 \\
\hline 9 & 1 & 0 & -1 & -1 & 40 & 129.16 & 27.19 \\
\hline 10 & 3 & 0 & 1 & -1 & 50 & 127.15 & 25.69 \\
\hline 11 & 10 & 0 & -1 & 1 & 45 & 126.3 & 40.1 \\
\hline 12 & 8 & 0 & 1 & 1 & 50 & 136.4 & 31.2 \\
\hline 13 & 9 & 0 & 0 & 0 & 45 & 123.5 & 41.23 \\
\hline 14 & 5 & 0 & 0 & 0 & 45 & 124 & 30.34 \\
\hline 15 & 11 & 0 & 0 & 0 & 45 & 127 & 44.3 \\
\hline 16 & 12 & 0 & 0 & 0 & 35 & 125 & 42 \\
\hline 17 & 4 & 0 & 0 & 0 & 45 & 123.5 & 38.67 \\
\hline
\end{tabular}

Table 7. Result of regression analysis for responses from RSM technique.

\begin{tabular}{ccccccc}
\hline Source & Musculoskeletal discomfort $(\%)$ & \multicolumn{2}{c}{ Heart rate (beats/min.) } & \multicolumn{2}{c}{$\begin{array}{c}\text { Volume of maximum oxygen } \\
\text { uptake (l/minute) }\end{array}$} \\
\hline & Coefficient & P value & Coefficient & P value & Coefficient & P value \\
\hline Model & 43.00 & 0.0084 & 124.6 & 0.0062 & 39.308 & 0.7495 \\
$\mathrm{X}_{1}$ & 12.51 & 0.0002 & 1.76875 & 0.0148 & 1.31125 & 0.6687 \\
$\mathrm{X}_{2}$ & 3.12 & 0.1081 & 1.35125 & 0.0439 & -1.08375 & 0.7230 \\
$\mathrm{X}_{3}$ & 3.13 & 0.1081 & 0.8325 & 0.1745 & 1.3725 & 0.6544 \\
$\mathrm{X}_{1}, \mathrm{X}_{2}$ & 0.000 & 1.0000 & 0.255 & 0.7530 & 4.1625 & 0.3495 \\
$\mathrm{X}_{1}, \mathrm{X}_{3}$ & -2.50 & 0.3322 & 0.5675 & 0.4900 & -4.34 & 0.3307 \\
$\mathrm{X}_{2}, \mathrm{X}_{3}$ & -1.25 & 0.6185 & 3.0275 & 0.0060 & -1.85 & 0.6694 \\
$\mathrm{X}_{1,2}$ & -2.12 & 0.3938 & 0.13 & 0.8689 & 1.31475 & 0.7548 \\
$\mathrm{X}_{2,2}$ & 1.63 & 0.5096 & 0.65 & 0.4204 & -1.99525 & 0.6371 \\
$\mathrm{X}_{3,2}$ & 1.62 & 0.5096 & 4.5025 & 0.0006 & -6.26775 & 0.1654 \\
$\mathrm{R}^{2}$ & 0.9016 & & 0.9104 & & 0.4455 & 0.62 \\
F Value & 7.12 & 7.91 & & $\mathrm{NS}$ \\
Lack of fit & $\mathrm{NS}$ & $\mathrm{NS}$ & & \\
\hline
\end{tabular}

Table 8. ANOVA for musculoskeletal discomfort (MSD) during experiment.

\begin{tabular}{lllll}
\hline Source & Df & Sum of square & Mean of square & F Value \\
\hline Model & 9 & 1476.99 & 164.11 & $7.12^{* * *}$ \\
Linear & 3 & 1406.26 & 468.75 & $20.34^{* * *}$ \\
Quadratic & 3 & 31.25 & 10.41 & 0.45 \\
Interactive & 3 & 41.25 & 13.75 & 0.59 \\
Error & 7 & 161.25 & 23.03 & \\
Total & 16 & 1640.01 & & \\
\hline
\end{tabular}

$* * *, * * *$ significant at 1,5 and $10 \%$ level of significance respectively;

$\mathrm{F}$ tab value $(9,7)=6.71 ; \mathrm{F}$ tab value $(3,7)=8.45(1 \%)$

$\mathrm{F}$ tab value $(9,7)=3.67 ; \mathrm{F}$ tab value $(3,7)=4.34(5 \%)$

$\mathrm{F}$ tab value $(9,7)=2.72 ; \mathrm{F}$ tab value $(3,7)=3.07(10 \%)$ 
Table 9. Total effect of individual parameter on musculoskeletal discomfort (MSD) experiment.

\begin{tabular}{lllll}
\hline Source & Df & $\begin{array}{l}\text { Sum of } \\
\text { square }\end{array}$ & $\begin{array}{l}\text { Mean of } \\
\text { square }\end{array}$ & F Value \\
Model & 9 & 1476.99 & 164.11 & $7.12 * * *$ \\
Load & 4 & 1294.01 & 323.50 & $14.04 * * *$ \\
weight $\left(\mathbf{x}_{\mathbf{1}}\right)$ & & & & \\
Height $\left(\mathbf{x}_{2}\right)$ & 4 & 95.5 & 23.87 & 1.03 \\
Time $\left(\mathbf{x}_{3}\right)$ & 4 & 120.5 & 30.12 & 1.30 \\
Error & 7 & 161.25 & 23.03 & \\
Total & 19 & 1671.26 & & \\
\hline
\end{tabular}

***, **, * significant at 1,5 and $10 \%$ level of significance respectively

$\mathrm{F}$ tab value $(9,7)=6.71 ; \mathrm{F}$ tab value $(4,7)=7.84(1 \%)$

$\mathrm{F}$ tab value $(9,7)=3.67 ; \mathrm{F}$ tab value $(4,7)=4.12(5 \%)$

$\mathrm{F}$ tab value $(9,7)=2.72 ; \mathrm{F}$ tab value $(4,7)=2.96(10 \%)$

Table 11. Total effect of individual parameter on heart rate (HR) experiment.

\begin{tabular}{llccc}
\hline Source & Df & $\begin{array}{l}\text { Sum of } \\
\text { square }\end{array}$ & $\begin{array}{l}\text { Mean of } \\
\text { square }\end{array}$ & F Value \\
\hline Model & 9 & 172.80 & 19.20 & $7.91^{* * *}$ \\
Load & 4 & 26.64 & 6.66 & 2.75 \\
weight $\left(\mathbf{x}_{\mathbf{1}}\right)$ & & & & \\
Height $\left(\mathbf{x}_{\mathbf{2}}\right)$ & 4 & 53.31 & 13.32 & $5.51^{* *}$ \\
Time $\left(\mathbf{x}_{\mathbf{3}}\right)$ & 4 & 128.85 & 32.21 & $13.31^{* * *}$ \\
Error & 7 & 17 & 2.42 & \\
Total & 19 & 225.8 & & \\
\hline
\end{tabular}

$* * *, * *, *$ significant at 1,5 and $10 \%$ level of significance respectively

$\mathrm{F}$ tab value $(9,7)=6.71 ; \mathrm{F}$ tab value $(4,7)=7.84(1 \%)$

$\mathrm{F}$ tab value $(9,7)=3.67 ; \mathrm{F}$ tab value $(4,7)=4.12(5 \%)$

$\mathrm{F}$ tab value $(9,7)=2.72 ; \mathrm{F}$ tab value $(4,7)=2.96(10 \%)$

Table 13. Total effect of individual parameter on total cardiac cost of work (TCCW) experiment.

\begin{tabular}{lllll}
\hline Source & df & $\begin{array}{l}\text { Sum of } \\
\text { square }\end{array}$ & $\begin{array}{l}\text { Mean of } \\
\text { square }\end{array}$ & F Value \\
\hline Model & 9 & 228496.67 & 15388.51 & 3.52 \\
Load weig $\left(\mathbf{x}_{\mathbf{1}}\right)$ & 4 & 1865 & 4662.77 & 0.65 \\
Height $\left(\mathbf{x}_{\mathbf{2}}\right)$ & 4 & 15328.87 & 3832.21 & 0.53 \\
Time $\left(\mathbf{x}_{\mathbf{3}}\right)$ & 4 & 208114.8 & 52028.71 & $7.23^{* *}$ \\
Error & 7 & 50358.60 & 7194.08 & \\
Total & 19 & 275667.3 & & \\
\hline
\end{tabular}

$* * *, * *, *$ significant at 1,5 and $10 \%$ level of significance respectively

$\mathrm{F}$ tab value $(9,7)=6.71 ; \mathrm{F}$ tab value $(4,7)=7.84(1 \%)$

$\mathrm{F}$ tab value $(9,7)=3.67 ; \mathrm{F}$ tab value $(4,7)=4.12(5 \%)$

$\mathrm{F}$ tab value $(9,7)=2.72 ; \mathrm{F}$ tab value $(4,7)=2.96(10 \%)$
Table 10. ANOVA for heart rate (HR) during experiment.

\begin{tabular}{llllll}
\hline Source & Df & $\begin{array}{l}\text { Sum of } \\
\text { square }\end{array}$ & $\begin{array}{l}\text { Mean } \\
\text { square }\end{array}$ & of & F Value \\
Model & 9 & 172.80 & 19.20 & $7.91^{* * * *}$ \\
Linear & 3 & 45.17 & 15.05 & $6.22^{* *}$ \\
Quadratic & 3 & 38.21 & 12.74 & $5.26^{* *}$ \\
Interactive & 3 & 87.21 & 29.07 & $12.01^{* * *}$ \\
Error & 7 & 17 & 2.42 & \\
Total & 16 & 187.59 & & \\
\hline
\end{tabular}

$* * *, * *, *$ significant at 1,5 and $10 \%$ level of significance respectively

$\mathrm{F}$ tab value $(9,7)=6.71 ; \mathrm{F}$ tab value $(3,7)=8.45(1 \%)$

$\mathrm{F}$ tab value $(9,7)=3.67 ; \mathrm{F}$ tab value $(3,7)=4.34(5 \%)$

$\mathrm{F}$ tab value $(9,7)=2.72 ; \mathrm{F}$ tab value $(3,7)=3.07(10 \%)$

Table 12. ANOVA for maximum volume of oxygen consumption $\left(\mathrm{VO} 2_{\max }\right)$ during experiment.

\begin{tabular}{lllll}
\hline Source & Df & $\begin{array}{l}\text { Sum of } \\
\text { square }\end{array}$ & $\begin{array}{l}\text { Mean of } \\
\text { square }\end{array}$ & F Value \\
\hline Model & 9 & 387.89 & 43.09 & 0.62 \\
Linear & 3 & 38.21 & 12.74 & 0.18 \\
Quadratic & 3 & 158.33 & 52.77 & 0.76 \\
Interactive & 3 & 189.43 & 63.14 & 0.91 \\
Error & 7 & 482.83 & 68.97 & \\
Total & 16 & 868.8 & & \\
\hline
\end{tabular}

$* * *, * *, *$ significant at 1,5 and $10 \%$ level of significance respectively

$\mathrm{F}$ tab value $(9,7)=6.71 ; \mathrm{F}$ tab value $(3,7)=8.45(1 \%)$

$\mathrm{F}$ tab value $(9,7)=3.67 ; \mathrm{F}$ tab value $(3,7)=4.34(5 \%)$

$\mathrm{F}$ tab value $(9,7)=2.72 ; \mathrm{F}$ tab value $(3,7)=3.07(10 \%)$

Table 14. Constraints for optimization of parameters.

\begin{tabular}{|c|c|c|c|c|}
\hline Name & Goal & $\begin{array}{l}\text { Lower } \\
\text { Limit }\end{array}$ & $\begin{array}{l}\text { Upper } \\
\text { limit }\end{array}$ & $\begin{array}{c}\text { Goal } \\
\text { setting }\end{array}$ \\
\hline Load weight & In range & -1 & 1 & +++ \\
\hline Ramp height & In range & -1 & 1 & +++ \\
\hline Time & $\begin{array}{l}\text { mini- } \\
\text { mum }\end{array}$ & -1 & 1 & +++++ \\
\hline $\begin{array}{l}\text { Muscu- } \\
\text { loskeletal } \\
\text { discomfort } \\
\text { (MSD) }\end{array}$ & $\begin{array}{l}\text { mini- } \\
\text { mum }\end{array}$ & -1 & 1 & ++++ \\
\hline $\begin{array}{l}\text { Heart rate } \\
(\mathrm{HR})\end{array}$ & $\begin{array}{l}\text { mini- } \\
\text { mum }\end{array}$ & -1 & 1 & +++++ \\
\hline $\begin{array}{l}\text { Volume of } \\
\text { maximum } \\
\text { oxygen up- } \\
\text { take (VO2 } \\
\text { max) }\end{array}$ & $\begin{array}{l}\text { mini- } \\
\text { mum }\end{array}$ & -1 & 1 & ++++ \\
\hline
\end{tabular}

Table 15. Optimum values of parameters for experimentation of loading ramp.

\begin{tabular}{cccccccc}
\hline Value & $\begin{array}{c}\text { Load weight } \\
(\mathbf{k g} .)\end{array}$ & $\begin{array}{c}\text { Height } \\
(\mathbf{f e e t})\end{array}$ & $\begin{array}{c}\text { Time } \\
(\text { minutes })\end{array}$ & $\begin{array}{c}\text { MSD } \\
(\mathbf{\%})\end{array}$ & $\begin{array}{c}\text { HR } \\
\text { (Beats/min.) }\end{array}$ & $\begin{array}{c}\text { VO2 max } \\
(\mathbf{l} / \mathbf{m i n} \text {. })\end{array}$ & Desirability \\
\hline Coded & -1 & -1 & -.71 & & & & \\
Actual & 40 & 3 & 3.29 & 22.80 & 126.76 & 34.00 & 0.84 \\
\hline
\end{tabular}




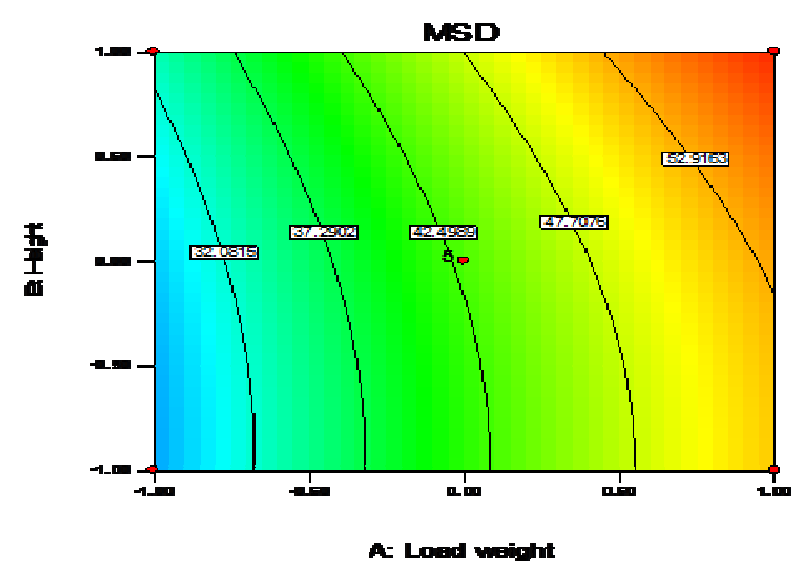

A1: Effect of loadweight and height on MSD

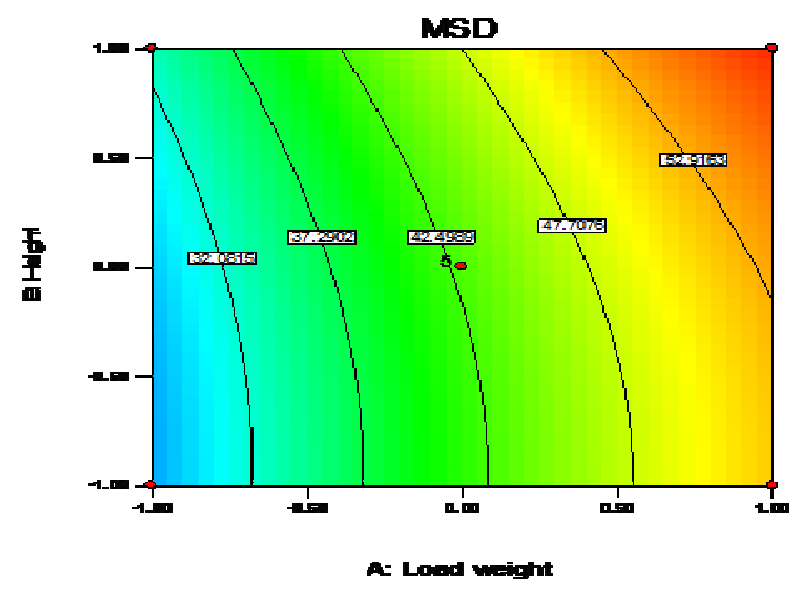

A2. Effect of load weight and time on MSD

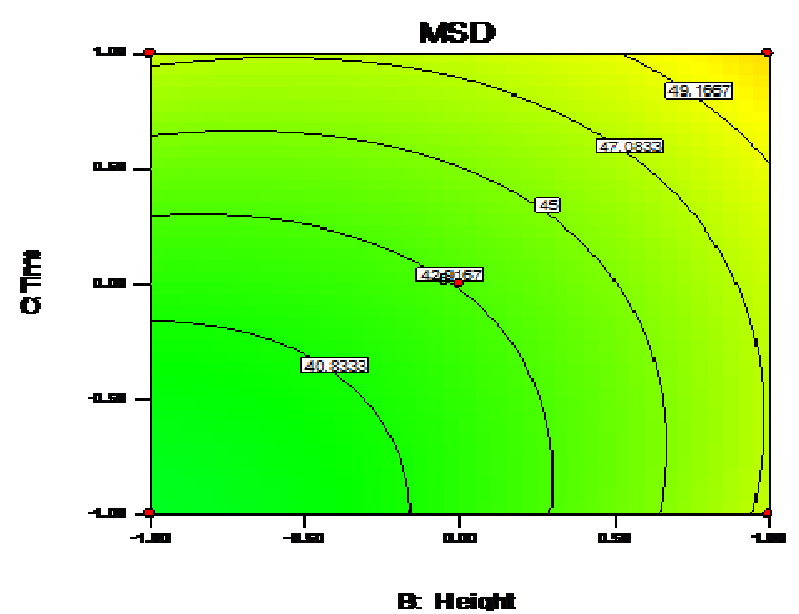

A3. Effect of height and time on MSD

Fig. 1 (A1-A3): Contour plots for musculoskeletal discomfort (MSD) during experiment.

machinery should be considered in relation to both the body dimension of individual Hence the variation

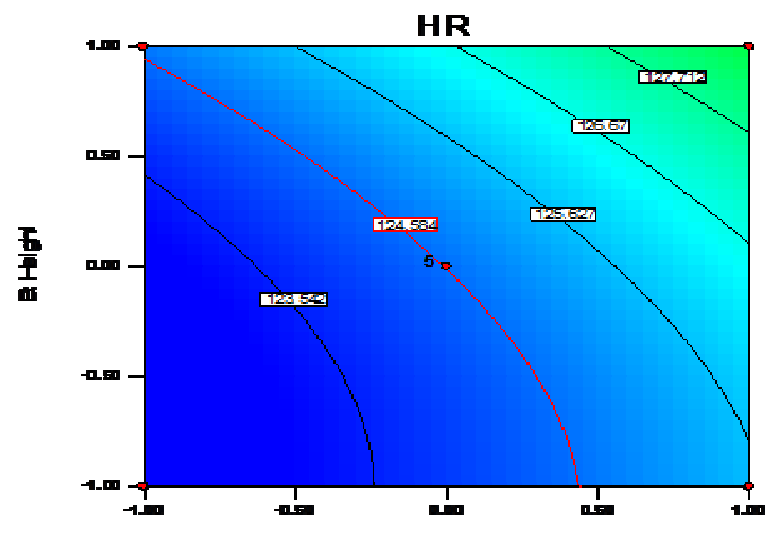

A: Load weinht

A1: Effect of loadweight and height on HR

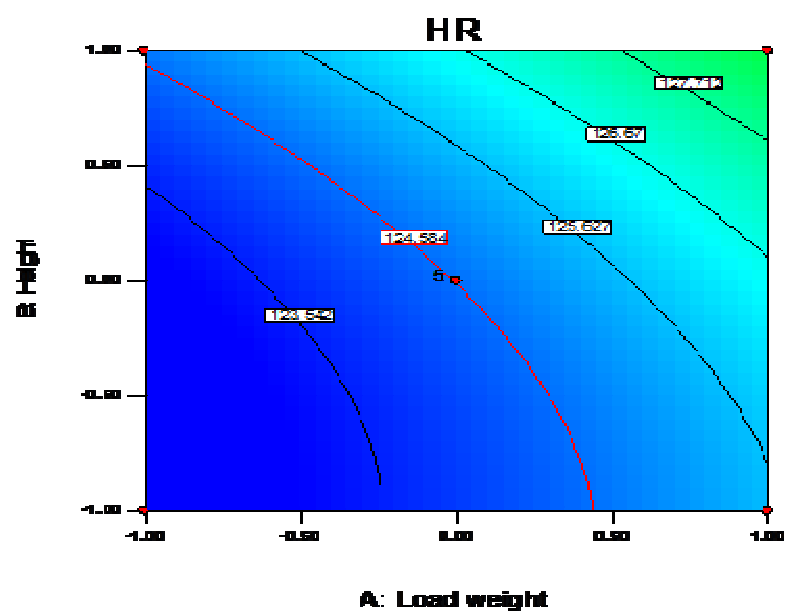

A2. Effect of load weight and time on $H R$

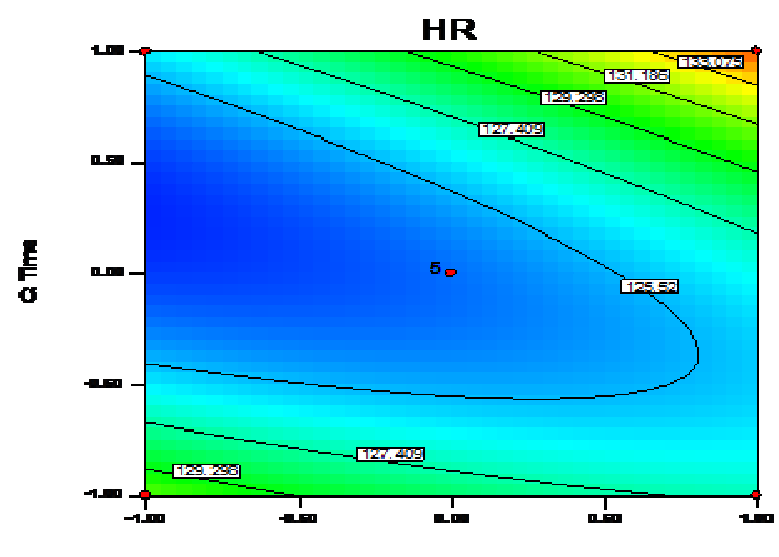

B: Hoipht

A3. Effect of height and time on $H R$

Fig. 2 (A1-A3): Contour plots for heart rate (HR) during experiment.

of the individual body dimensions should be given the emphasis when a design problem is tackled. It is 


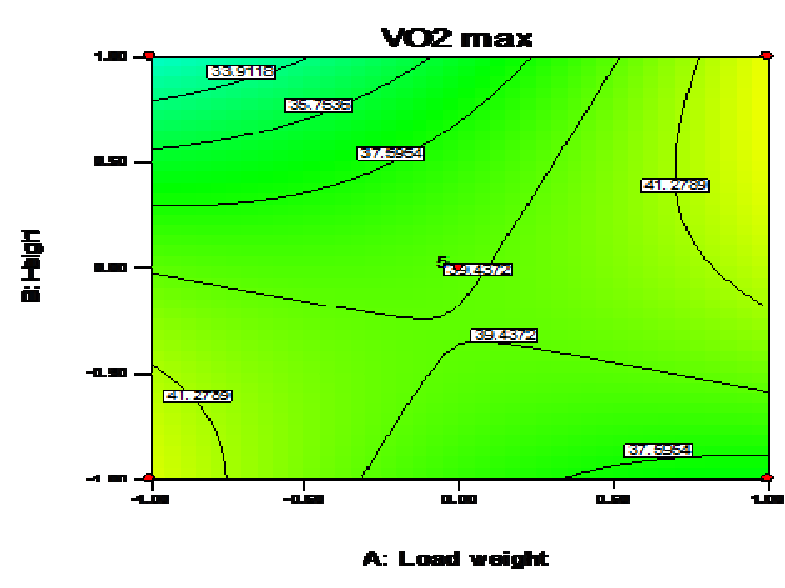

A1. Effect of load weight and height on $\mathrm{VO}_{2}$ max.

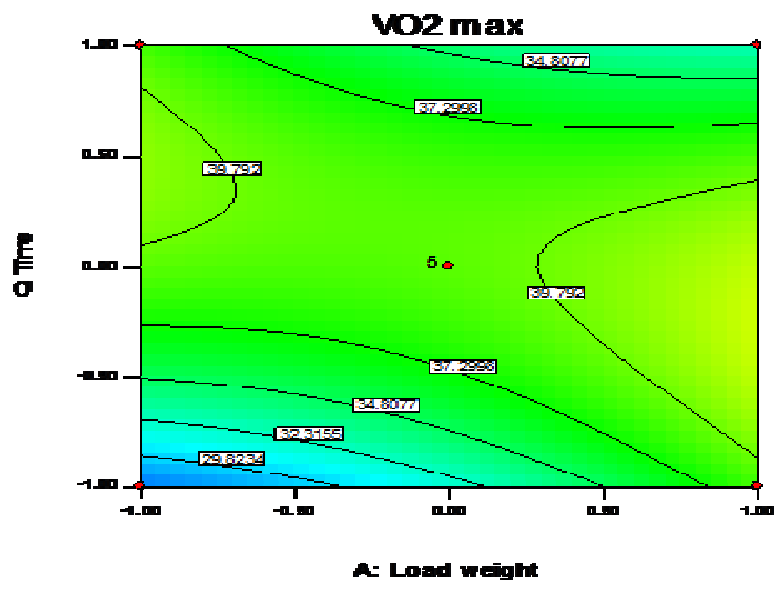

A2. Effect of load weight and time on $\mathrm{VO}_{2}$ max.

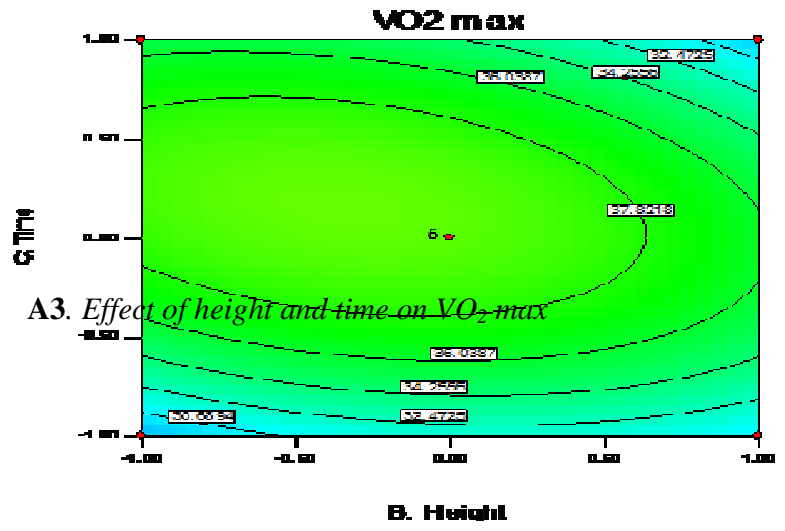

Fig. 3: Contour plots for volume of maximum oxygen uptake $\left(\mathrm{VO}_{2}\right.$ max) during experiment.

widely agreed that use of $5^{\text {th }}, 50^{\text {th }}$ or $95^{\text {th }} \%$ ile value of various body measurement is more logical in design considerations.

Conventional Loading ramp: The conventional loading ramp (wooden plank) was used from the past several years and was made up of wood in rectangular

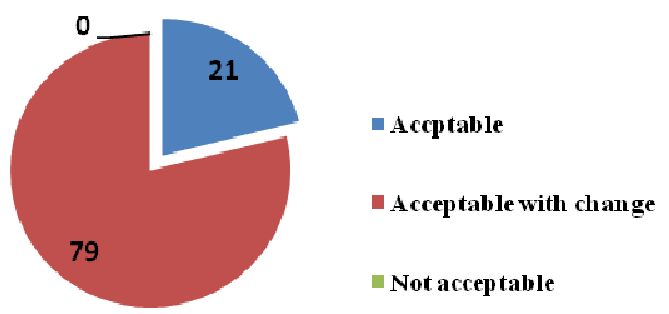

Loading ramp

Fig. 4 User's acceptability with relative use of developed loading ramp.

Table 16. Comparative evaluation of pant loading ramp

\begin{tabular}{|c|c|c|c|}
\hline S.No. & Physiological parameters & $\begin{array}{l}\text { Woode } \\
\text { n plank }\end{array}$ & $\begin{array}{l}\text { Pant } \\
\text { Loading } \\
\text { ramp }\end{array}$ \\
\hline $\mathbf{1}$ & $\begin{array}{l}\text { Average working heart } \\
\text { rate (AWHR) }\end{array}$ & 135.4 & 126.76 \\
\hline 2 & Peak heart rate (PHR) & 141 & 130.2 \\
\hline 3 & $\begin{array}{l}\text { Musculoskeletal discom- } \\
\text { fort (MSD) }\end{array}$ & 85.45 & 22.80 \\
\hline 4 & $\begin{array}{l}\text { Volume of maximum oxy- } \\
\text { gen uptake }(\mathrm{VO} 2 \max )\end{array}$ & 39.45 & 34 \\
\hline 5 & $\begin{array}{l}\text { Total cardiac cost of work } \\
\text { (TCCW) }\end{array}$ & 996.3 & 564.36 \\
\hline
\end{tabular}

shape with the length of 12 feet, width of 1 foot, thickness of 2 inch and the rubber stripes were sticked on it, to make it anti slippery. It was found as very heavy and there was no provision to make it static on the different loading heights. For this purpose the workers were using the conventional drum to hold and make it in static position during loading and unloading activities. In terms of tool designing, Koivunen (1994) designed the cleaning equipment and reported that the redesign of the tool was based on the problem analysis and participation of the cleaners in user-centered design. Many researchers have emphasized the idea of a usercentered approach in designing hand tools (Kardborn, 1998; Pheasant, 1996). In one "Swedish hand tool project" the user-centered approach was the basis for designing 10 non powered hand tools, and it was found that user participation was an effective method that provided important information for specification, design and evaluation of improved hand tool design (Kardborn, 1998). Some studies suggested that general judgement of the tool/operator situation in design aspect is often needed, and the "cube model" (Sperling et al., 1993) and "over exertion model" (Kumar, 1994) also provide a good basis for such judgement.

Design and development of aluminium loading ramp : On the basis of evaluation of conventional tools need was felt to redesign and develop a loading ramp technology especially for worker to improve their health, safety and productivity. The design was based on the existing basic design of wooden plank, which were poorly designed and not found to be suit- 
able, according to the need of users. These were causing to drudgery during activities because it is used for longer duration and its operation demands more energy and time. During the redesign and development phase it was observed that there was tremendous scope of improvement to get the best output. In addition to the open observation, interviews were carried out to get the feedback of the following working tool.

Optimization of process parameters using response surface methodology (RSM): Response surface methodology (RSM) is a collection of mathematical and statistical techniques for empirical model building by careful design of experiments (Sampaio et al., 2006). The objective of it's to optimize a response (output variable) which is influenced by several independent variables (input variables) (Alvarez, 2000). An experiment is a series of tests, called runs, in which changes are made in the input variables in order to identify the reasons for changes in the output response. Therefore in this study the RSM was applied to optimize the operating parameters (load weight, height of ramp and time) consider during the experiment. As per Box Behenken design total 17 experiments were carried out. Each parameter was varied over three levels. The load weight of the sacs were varies over three levels as 40,50 and $60 \mathrm{~kg}$. The height of the ramp was varied over three ranges 3, 4 and 5 feet. Whereas the loading time while experiments were also varied over the three levels viz. 3, 4 and $5 \mathrm{~min}$. The responses selected were musculoskeletal discomfort, heart rate and volume of maximum oxygen uptake ( $\mathrm{VO} 2_{\max }$ ). ANOVA test was applied to evaluate the adequacy (by applying the lack-of-fit test) of different models and to evaluate the statistical significance of the factors in the model. In order to examine the goodness and evaluate the adequacy of a fitted model, the coefficient of determination $\left(\mathrm{R}^{2}\right)$ was calculated. The surfer software 9.0 was employed for the graphical optimization; similar techniques were also reported by Pishgar et al. (2012).

Development of second order model : A complete second mathematical model (Eqn 1) model was fitted to the data and adequacy of the model was tested considering the coefficient of multiple determinations $\left(\mathrm{R}^{2}\right)$, fisher's F-test and lack of fit. The model was then used to interpret the effect of various parameters on the response. Optimization of process parameter was carried out at the end of analysis. The optimized value of process parameter was used and contours were developed for selected parameters.

Second order model was used to interpret the effect of load weight, ramp height and time of load carrying on back on various response (table 6) musculoskeletal discomfort, heat rate (HR) and volume of maximum oxygen uptake (VO2 max). Complete second order model was fitted to the data and adequacy of the model was tested consider $\mathrm{R}^{2}$ and $\mathrm{F}$ test.
The second order mathematical response function for three independent variables has the following general form:

$y=B 0 \sum_{i=1}^{n} B i \times i+\sum_{i=1}^{2} \sum_{j=i+1}^{n} B i j \times i \times j+\sum_{i=1}^{n} B i x^{2}$ Eqn.1

Experimental data were analyzed by employing multiple regression technique to develop response functions and variable parameters were optimized for the best outputs. The regression coefficient of the complete second order model and their significance has been reported in the table 7. High $P$ value indicated that a model had a significant lack of fit and therefore considered to be inadequate. The lower the value of $\mathrm{P}$, better would be model. The model having $\mathrm{P}$ value lower than 0.1 were accepted.

Effect of independent variables on different responses: By response surface methodology, a complete realization of the process parameters and their effects were achieved under following heads:

Effect of load weight, height and time on musculoskeletal discomfort (MSD): The musculoskeletal discomfort during the whole set of experiment ranged from 1 to 17 over entire experiment condition. Maximum MSD was observed from experiment number 8 having load weight of $60 \mathrm{~kg}$., height 4 feet, and time 5 minute, while minimum MSD was observed from experiment number 5 at load weight $40 \mathrm{~kg}$., height 4 feet and the time period was 3 minute. The main reason behind these variations in MSD was that the load weight and time was decreased in experiment number 5 .

Significance of independent variable i.e. loads weight, height and time on MSD data was tested using ANOVA. Total effect of individual parameters was also assessed using ANOVA and the details are tabulated in table 8.Full second order model was fitted to MSD and other various experiment conditions using multiple regression analysis. Table 9 reports the result of regression analysis of MSD. The coefficient of determination $\left(\mathrm{R}^{2}\right)$ regression model for this parameter was found 0.90 , which implies that the model account for $90 \%$ variability in data. The second order model was found to be highly significant at $1 \%$ level of significance with $\mathrm{F}$ value of 7.12 and non significant lack of fit. Hence, second order model was found to be adequate in describing the behaviour of MSD with respect to dependent variables because it has higher $\mathrm{R}^{2}$ and $\mathrm{F}$ value.

Effect of load weight, height and time on heart rate (HR): The heart rate data during the whole set of experiment ranged from 1 to 17 over entire experiment condition. Maximum heart rate was observed from experiment number 12 having load weight of $50 \mathrm{~kg}$., height 5 feet, and time was 5 minute, while minimum heart rate was observed from experiment number 1 at 
load weight $40 \mathrm{~kg}$., height 3 feet and the time period was 4 minute. The main reason behind these variations in heart rate was that the load weight and time was reduced in experiment number 1 .

Significance of independent variable i.e. loads weight, height and time on heart rate data was tested using ANOVA. Total effect of individual parameters was also assessed using ANOVA and the details are tabulated in 10.significant. Hence, second order model was found to be adequate in describing the behaviour of heart rate with respect to dependent variables because it has higher $\mathrm{R}^{2}$ and $\mathrm{F}$ value.

Effect of load weight, height and time on maximum volume of oxygen consumption ( $\left.\mathrm{VO2} 2_{\max }\right)$ : The maximum volume of oxygen consumption $\left(\mathrm{VO} 2_{\max }\right)$ data during the whole set of experiment ranged from 1 to 17 over entire experiment condition. Maximum $\mathrm{VO} 2_{\max }$ was observed from experiment number 4 having load weight of $60 \mathrm{~kg}$., height 5 feet, and time was 4 minute, whereas minimum $\mathrm{VO} 2_{\max }$ was observed from experiment number 8 at load weight $60 \mathrm{~kg}$., height 4 feet and the time period was 5 minute. The main reason behind this variation in TCCW was that the, height was reduced in experiment number 5, whereas the time and weight was equal to the experiment number 4 .

Significance of independent variable i.e. loads weight, height and time on $\mathrm{VO} 2_{\max }$ data was tested using ANOVA. Total effect of individual parameters was also assessed using ANOVA and the details are tabulated in 12.Full second order model was fitted to $\mathrm{VO} 2_{\max }$ and other various experiment conditions using multiple regression analysis. Table 13 reports the result of regression analysis of $\mathrm{VO} 2_{\max }$. The coefficient of determination $\left(\mathrm{R}^{2}\right)$ regression model for this parameter was found very less 0.44 , which implies that the model account for only $44 \%$ variability in data. The second order model was not found to be significant at $1 \%, 5 \%$ and $10 \%$ level of significance with $\mathrm{F}$ value of 0.62 with the non significant lack of fit. Hence, second order model was not found to be adequate in describing the behaviour of $\mathrm{VO} 2_{\max }$ with respect to dependent variables because it has lower $\mathrm{R}^{2}$ and $\mathrm{F}$ value.

Optimization of parameters (load weight, height and time) for described responses: Numerical optimization was carried out using design software. The goal was fixed to minimize heart rate, energy expenditure and musculoskeletal disorder. The responses i.e. musculoskeletal discomfort, heart rate (HR) and volume of maximum oxygen uptake $\left(\mathrm{VO} 2_{\max }\right)$ were taken into consideration for optimization. The goal seeking begins at a random starting point and proceeds up and down the steepest slope on the response surface for a maximum and minimum value of the response respectively. Importance to the responses and independent variables were given on the basis of the objective of the study. Maximum importance was $(+++++)$ was given to time and heart rate, next importance were given to the musculoskeletal disorder (MSD) (++++) and volume of maximum oxygen uptake $\left(\mathrm{VO} 2_{\max }\right)$, while the goal of load weight and height (+++) was kept at in range similar study was also reported by Rai et al. (2012). The goal setup and optimum value of different parameters obtained is given in table 14

During optimization 17 solution were obtained, out of which the most suitable criteria, was selected. The selected solution was tested for the actual conditions and it was observed out of three independent variable. Optimum results were obtained when the load weight $40 \mathrm{~kg}$., height 3 feet and time 3.29 minute.

Optimization of the design parameters for development of an appropriate loading ramp: The numerical values investigated the independent design parameters of the ramp to obtain the optimum human capacity and efficiency. The surfur software 9.0 was employed for the optimization of the multiple responses. The desired goals (maximize or minimize) for each variable and response were chosen and different weights (i.e. a number between 0.1 and 1.0, which shows the importance of the desired goal) were assigned to each goal to adjust the shape of its particular desirability function. The optimised values of variables (table 15) such as load weight 40 $\mathrm{kg}$., ramp height 3 feet and time 3.29 minute were determined. On this basis, a new loading ramp, having a height 3 feet $\mathrm{mm}$, time 3.29 minutes and load weight of $40 \mathrm{~kg}$ leads to MSD i.e. $22.80 \%$ with heart rate of 126.76 beats/min. and $\mathrm{VO} 2_{\max } 34 \mathrm{~L} /$ min. with overall desirability were found to be 0.84 $\%$. Hence, this combination shows the maximum efficiency with minimum time, energy and musculoskeletal disorder was obtained by loading ramp.

Graphical optimization : In order to show the effect of variable (load weight, height and time) and to determine the operating range for best results, contour plot was drawn and shown in Fig 1 to 2 for various combinations of interactive term either at optimum value or centre point.

Optimization of process parameters for MSD: Optimization of processing condition using surfer software was carried out to minimize the ergonomic problems and increased efficiency. The MSD at optimum was found to be $22.80 \%$. Contour plot Fig. 1 (A1) depicts the effect of load weight and height on MSD. It was observed that MSD was increased with the load weight of rice sack and height of the ramp.

Fig. 1 (A2) shows the effect of both time and load weight on MSD, it was observed that MSD was increased in linear pattern with the time and load weight increased. Whereas Fig. 1 (A3) also shows the effect of ramp height and time on MSD. Hence, it was observed that both time and height affects the MSD rates. Optimization of process parameters for heart rate: The heart rate at optimum was found to be 126.76 
beats/min. Fig. 2(A1) depicting the effect of load weight and height on heart rate, it was observed that heart rate was found to be increased with the both, ramp height and load weight. From Fig.2 (A2) which shows the effect of load weight and time on heart rate, it was observed that only time, affects the heart rate parameters. Whereas Fig. 2 (A3) shows the effect of ramp height and time on heart rate. Therefore it was observed that only time affects the heart rate of human body .

Optimization of process parameters for volume of oxygen consumption $\left(\mathbf{V O}_{2}\right.$ max): The volume of maximum oxygen consumption $\left(\mathrm{VO} 2_{\max }\right)$ at optimum was found to be $34.00 \mathrm{~L} / \mathrm{min}$. Fig. 3 (A1) depicting the effect of load weight and height on $\mathrm{VO} 2_{\max }$ at centre point and it shows a minimum region at centre which is called as saddle point and showed that there is no effect of load weight and height on $\mathrm{VO} 2_{\max }$. Whereas Fig. 3 (A2), also showed a minimum region at centre which is called as saddle point and showed that there is no effect of load weight and time on $\mathrm{VO}_{2}$ max. Fig. 3 (A3) shows the effect of time and ramp height on $\mathrm{VO} 2_{\max }$, it was observed that only time rather than height affects the $\mathrm{VO} 2_{\text {max }}$ parameters.

Comparative performance of the pant loading ramp and existing wooden plank.: Use of developed loading ramp was able to reduce average working heart rate of selected respondents from 135.4 beats $/ \mathrm{min}$. to 126.76 beats/min., peak heart rate from 141-130.2 beats/min. musculoskeletal discomfort from 85.45 to $22.80 \%$, VO2 max from 39.45 to $34 \mathrm{~L} / \mathrm{min}$. and TCCW from 996.3 to 564.36 beats. It means the energetic workload and perceived discomfort of the respondents in different body regions differ significantly for the use of both traditional and developed loading ramp.Out of 10 subjects 7 were rated the conventional wooden plank as physically and physiologically more demanding than modern ones and it was able to reduce the preparation time of loading platform from $45 \mathrm{~min}$. to $5 \mathrm{~min}$. Thus the acceptability and usability of developed loading ramp was more than $60 \%$ as reported by the selected subjects.

User's acceptability of pant loading ramp : User's acceptability of improved loading ramp was assessed on the basis of three point continuum i.e. acceptable, acceptable with change and not acceptable. Data regarding acceptability of loading ramp showed that $21 \%$ respondents were agreed that it is acceptable as such, while rest i.e. $79 \%$ respondents were agreed that it was acceptable with some changes like length of the ramp.

\section{Conclusion}

The machine efficiency of a new loading ramp was found optimum on having a height 3 feet $\mathrm{mm}$, time 3.29 minutes and load weight of $40 \mathrm{~kg}$ leads to the MSD i.e. $22.80 \%$ with heart rate of 126.76 beats/ min. and $\mathrm{VO}_{2}{ }_{\max } 34 \mathrm{~L} / \mathrm{min}$. with overall desirability were found to be $0.84 \%$. Hence, this combination shows the maximum efficiency with minimum time, energy and musculoskeletal disorder was obtained by loading ramp.

\section{ACKNOWLEDGEMENTS}

The authors would like to thank to employers and employees who participated in the study and University Grant Commission for funding.

\section{REFERENCES}

Alvarez, L.E. (2000). Approximation model building for design optimization using the RSM and genetic programming, Ph.D. thesis, depertment of civil and environmatal engineering, university of Brandford, UK..

Edlich, R.F., Hudson, M.A., Buschbacher, R.M., Winters, K.L., Britt, L.D., Cox, M.J., Becker, D.G., McLaughlin, J.K., Gubler, K.D. and Zomerschoe, T.S. et al. (2005). Devastating injuries in healthcare workers: Description of the crisis and legislative solution to the epidemic of back injury from patient lifting. Journal of Long Term Effects of Medical Implants, 15: 225-241.

Genaidy, A. M.; Christensen, D.M.; Nogiates, C. and Deraireh, N. (2003). What is heavy? Journal of Ergonomics, 41 (4): 420-432.

Health and Safety Authority. (2007). HSA summary of injury illness and fatality statistics 2005-2006.

Health and Safety Review. (2007). OIB figures suggest accidents increasing. January/February.

Hoozemans, M.J., van der B, A.J., Frings, D.M.H., van Dijk, F.J. and van der Woude, L.H. (1998). Pushing and pulling in relation to musculoskeletal disorders: A review of risk factors. Journal of Ergonomics, 41: 757-781.

Kardborn, A. (1998). Inter-organizational participation and user focus in a large-scale product development programme: The Swedish hand tool project. International Journal of Industrial Ergonomisc, 21: 369-381.

Koivunen, M.R. (1994). Actor Tools: tools for user interface modeling, developing and analysis.

Kumar, S. (1994). A conceptual model of overexertion, safety and risk of injury in occupational settings. $\mathrm{Hu}$ man Factors, 36: 197-209.

Kuorinka, A. et al. (1987). Participation in workplace design with reference to low back pain: a case for the improvement of the police patrol car. Ergonomics, 37 (7):11311136.

Natarajan, U., Periyanan, P.R. and Yang, S.H. (2011). Multipleresponse optimization for microend milling process using response surface methodology ; The international Journal of advanced Manufacturing Technolgy, 56 (1-4) 177.

National Institute for Occupational Safety and Health (NIOSH). (1997). Work-related musculoskeletal disorders (NIOSH Facts, document No. 705005). Washington, DC, USA; NIOSH.

Pheasant, S.T. (1996). Body space: anthropometry, ergonomics and design of work, $2^{\text {nd }}$ edition, Taylor $\&$ Francis, London.

Pishgar S.H. Komleh, Keyhan I.A., Mostofi, M.R., Sarkariand, A. and Jafari (2012). Application of Response Surface Methodology for Optimization of PickerHusker Harvesting Losses in Corn Seed. Iranica Journal of Energy \& Environment 3 (2): 134-142.

Rai, A. (2012). Ergonomic evaluation of conventional and 
Kumkum Pandey and Deepa Vinay / J. Appl. \& Nat. Sci. 8 (3): 1267 - 1277 (2016)

improved methods of aonla priking. Unpublished M.Sc. Thesis, Deptt. of Family Resource Management, CCS Haryana Agriculture University Hisar, India.

Sampaio, F.C., Defaveri, D., Mantovani, H.C., Passos, F.M.L., Perego, P. and Converti, A. (2006). Use of response surface methodology for optimization of xylitol production by the new yeast strain debaryomyces hansenii UFV-170. Journal of Food Engineering, 76: 376-86.

Sperling, L., Dahlman, S., Wikström, L., Kilbom, A. and Kadefors, R. (1993). A cube model for the classification of work with hand tools and the formulation of functional requirements. Journal of Applied Ergonomics, 24 (3): 212-230 